\title{
Pfeiffer-Palm-Teller syndrome
}

\author{
INSERM
}

\section{Source}

INSERM. (1999). Orphanet: an online rare disease and orphan drug data base. PfeifferPalm-Teller syndrome. ORPHA:2871

Pfeiffer-Palm-Teller syndrome is a very rare dysmorphic syndrome described in two sibs and characterized by a short stature, unique facies, enamel hypoplasia, progressive joint stiffness, high-pitched voice, cup-shaped ears, and narrow palpebral fissures with epicanthal folds, and intellectual deficit. 